\title{
Protein LYRIC
}

National Cancer Institute

\section{Source}

National Cancer Institute. Protein LYRIC. NCI Thesaurus. Code C92660.

Protein LYRIC (582 aa, $64 \mathrm{kDa}$ ) is encoded by the human MTDH gene. This protein is involved in transcriptional regulation, cell growth, and metastasis. 